
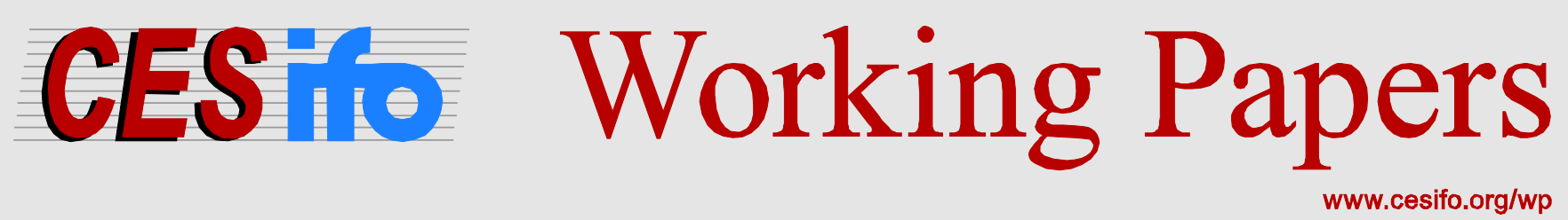

\title{
Collusive Tax Evasion and Social Norms
}

\author{
Martin Abraham \\ Kerstin Lorek \\ Friedemann Richter \\ Matthias Wrede
}
CESIFO WORKING PAPER NO. 5167
CATEGORY 1: PuBliC FINANCE
JANUARY 2015

ISSN 2364-1428

\footnotetext{
An electronic version of the paper may be downloaded

- from the SSRN website:

- from the RePEc website:

- from the CESifo website:

wWw.SSRN.com

www.RePEc.org

www.CESifo-group.org/wp
}

\section{CESifo}




\title{
Collusive Tax Evasion and Social Norms
}

\begin{abstract}
Although collusive tax evasion by buyers and sellers of commodities and also by employers and employees is widespread all over the world, it has rarely been analyzed in the tax evasion literature. To fill this gap and to compare collusive tax evasion with independent tax evasion, this paper develops a simple non-cooperative game-theoretic model and confirms the model's predictions in a laboratory experiment. Because collusive tax evasion involves social interaction, this paper focuses on the effect of social norms and theoretically and empirically demonstrates that the tax compliance norm has a stronger negative effect on the magnitude of collusive tax evasion than on independent tax evasion. The reason for this result is that in a collusive tax evasion game with multiple equilibria social norms act as an equilibrium selection device, whereas social norms need to be internalized to change the behavior of taxpayers who evade taxes unobservedly.
\end{abstract}

JEL-Code: H260, A130.

Keywords: collusive tax evasion, third-party reporting, social norms.

\author{
Martin Abraham \\ Friedrich-Alexander University \\ Erlangen-Nürnberg (FAU) \\ School of Business and Economics \\ PO Box 3931 \\ Germany - 90020 Nürnberg \\ martin.abraham@fau.de \\ Friedemann Richter \\ Friedrich-Alexander University \\ Erlangen-Nürnberg (FAU) \\ School of Business and Economics \\ PO Box 3931 \\ Germany-90020 Nürnberg \\ friedemann.richter@fau.de
}

\author{
Kerstin Lorek \\ Friedrich-Alexander University \\ Erlangen-Nürnberg (FAU) \\ School of Business and Economics \\ PO Box 3931 \\ Germany-90020 Nürnberg \\ kerstin.lorek@fau.de \\ Matthias Wrede* \\ Friedrich-Alexander University \\ Erlangen-Nürnberg (FAU) \\ School of Business and Economics \\ PO Box 3931 \\ Germany - 90020 Nürnberg \\ matthias.wrede@wiso.uni-erlangen.de
}

${ }^{*}$ corresponding author

This version: October 2014 


\section{Introduction}

Although third-party reporting and withholding taxes are powerful instruments to fight tax cheating, as shown in the recent literature, these instruments do not fully solve the tax enforcement problem. Third-party reporting may fail to fully enforce tax compliance because the affected parties have the opportunity to evade taxes collusively by explicitly or implicitly coordinating their behaviors and tax declarations. Collusive tax evasion by buyers and sellers was studied first by Yaniv (1992). Withholding taxes ensures tax payment only if the firm that is liable to pay the taxes faces sufficiently high audit rates. Arguing that taxed transactions by firms and audits are interrelated, Wrede (1993) demonstrated that low audit rates and fines are prohibitive given that the number of transactions subject to withholding taxation is sufficiently high. Similarly, Kleven, Kreiner, and Saez (2009) showed that collusion cannot be sustained in large firms that use verifiable business records. Kumler, Verhoogen, and Frias (2013) documented that under-reporting by formal firms in Mexico is extensive and that compliance is higher in larger firms.

Tax enforcement institutions in real-world tax systems often differ by taxes and tax bases; only a subset of taxes is covered by third-party reporting and withholding taxation. Therefore, in most countries, independent and collusive tax evasion co-exist, and their shares in total tax evasion are mainly determined by tax institutions. ${ }^{1}$ In many countries, taxes on capital income and profits can be evaded without the need for collusion, whereas the evasion of labor income taxes, social security contributions, and value-added taxes requires some sort of explicit or implicit collusion. On the one hand, a large share of the shadow economy indicates that collusive tax evasion is an important phenomenon; on the other hand, the absence of third-party reporting and information exchange provide room for independent tax evasion. Although precise and reliable estimates of the shadow economy and of the magnitude of evaded taxes associated with black market activities do not exist, ${ }^{2}$ there is clear evidence that in OECD countries, the shadow economy is not negligible (Schneider and Enste, 2000). For example, various surveys indicate that 10-21\%

\footnotetext{
${ }^{1}$ Tax evasion is deemed collusive if two or more taxpayers explicitly or implicitly coordinate their tax declarations to evade taxes, to reduce the likelihood of a tax audit, and/or to reduce the penalty; otherwise, it is deemed independent.

${ }^{2}$ Estimates for Germany 2007 vary between 2.8 - 14.7\% of GDP (Feld and Larsen, 2012).
} 
of Germans admitted that they had carried out undeclared work (Feld and Larsen, 2012).

Because the determinants of the occurrence and the magnitude of collusive tax evasion are not yet fully understood, although collusive evasion is sizeable, this paper examines the peculiarities of collusive tax evasion. In particular, it argues that social norms are notably important to understand whether and to what extent taxpayers collusively rather than independently evade taxes. The standard tax evasion model introduced in the seminal paper by Allingham and Sandmo (1972) considers a single individual who decides independently on the magnitude of tax evasion and evades taxes unwitnessed by any third party. Although Allingham and Sandmo (1972) already conceded that social norms affect the decisions of tax evaders, they mainly focused on the deterrent effect of audits and penalties. For many years, the coexistence of low audit rates and penalties and high compliance rates puzzled the literature (Andreoni, Erard, and Feinstein, 1998) and induced an intensive search for additional determinants of tax evasion (for an overview, see, e.g., Alm, 2012). In particular, the perceived benefits of taxes (Alm, McClelland, and Schulze, 1992) and trust in the legal system (Alm and Torgler, 2006) were found to increase tax morale. Following the work of Elster (1989) on social norms, many researchers argued that taxpayers comply conditional on the perceived behavior of others (see, e.g., Gordon, 1989; Myles and Naylor, 1996; Fortin, Lacroix, and Villeval, 2007; Traxler, 2010). Putnam (2001) provided descriptive evidence that social capital and tax compliance are strongly correlated. However, recently, it became evident that average audit rates do not translate directly into the probability of audit perceived by tax evaders. For example, some taxpayers overestimate audit probabilities (Scholz and Pinney, 1995; Chetty, 2009). Audit rates also differ across items and taxpayers. Klepper and Nagin (1989) showed that noncompliance rates are related to proxies for the traceability, deniability, and ambiguity of items, which are in turn related to the probability that evasion will be detected. Compliance rates are positively correlated with the presence of enforcement mechanisms such as third-party reporting and employer withholding (Slemrod, Blumenthal, and Christian, 2001; Slemrod, 2007; Alm, Deskins, and McKee, 2009). The influential paper by Kleven, Knudsen, Kreiner, Pedersen, and Saez (2011) on third-party reporting in Denmark also convincingly demonstrated that most taxpayers are unable to cheat, which implies that the deterrence model explains a large extent of the observed rate of tax evasion. Dwenger, 
Kleven, Rasul, and Rincke (2014) showed that $80 \%$ of church members behave as rational, self-interested taxpayers, consistent with the Allingham-Sandmo framework, and evade the "church tax". Saez (2010) found evidence of bunching around the first kink point of the Earned Income Tax Credit only among the self-employed, indicating huge differences in tax evasion between the self-employed and employees. These differences are attributed to the fewer opportunities for evasion held by the latter group.

However, even under third-party reporting and withholding taxation, tax evasion is still possible. ${ }^{3}$ If two or more individuals are involved in the taxed transaction, to successfully survive crosschecks, tax evaders must collude and synchronize their tax records. Despite its empirical relevance, few papers analyze collusive tax evasion explicitly. Assuming that cooperative tax evasion efforts reduce the detection probability more than individual efforts, Boadway, Marceau, and Mongrain (2002) analyzed penalty schemes and demonstrated that higher penalties might have adverse effects on tax compliance because they reduce the payoff of a unilateral deviation from the cooperative equilibrium. Modeling collusive tax evasion as a bargaining game between a seller and a buyer, Chang and Lai (2004) analyzed the effect of social norms on tax evasion and enforcement policies. They showed that social norms lead to a vicious circle of tax evasion: more prevalent tax evasion deteriorates social norms and therefore increases tax evasion itself. Social norms may also give rise to multiple equilibria. They also showed that penalties may induce more collaboration and therefore increase tax evasion if tax evasion is already widespread.

Rather than theorizing on the general equilibrium effects of social norms, this paper theoretically and empirically compares the direct effect of social norms on collusive tax evasion to its effect on independent tax evasion. Relying on Coleman's (1987, p. 135) definition that norms are "expectations about action - one's own action, that of others, or both - which express what action is right or what action is wrong" and combining it with Elster's (1989, p. 99) notion that a shared understanding and approval of norms by others is necessary to count as social norms, we define norms as common statements about

\footnotetext{
${ }^{3}$ Yaniv (1998) noted that wage earners that hold multiple jobs can evade taxes under progressive income taxation even under withholding taxation and fully compliant employers by misinforming employers regarding other employments, accompanied by not filing a tax return because this behavior results in the application of too low tax brackets.
} 
appropriate and accepted behavior in a specific situation. To affect the tax compliance of independently acting taxpayers, social norms need to be internalized, for example, through increased costs of cheating. An internally or externally enforced social norm has similar effects on the tax compliance of individuals who have the opportunity to evade taxes collusively. However, if colluding tax evaders act non-cooperatively because binding contracts are impossible, the institutional framework may give rise to multiple equilibria. Under these circumstances, (descriptive) social norms coordinate people's expectations and act as an equilibrium selection device (see, e.g., Young, 2008). This insight implies that social norms have a stronger deterring effect on collusive tax evasion compared to its effect on independent tax evasion. This paper shows that this intuition is correct and that the magnitude of the effect is sizeable. Using a simple non-cooperative game-theoretic framework, it is shown that for sufficiently low penalty rates, risk-neutral independent tax evaders evade their income completely, whereas collusion gives rise to multiple equilibria ranging from zero evasion to complete evasion. Social norms may act as an equilibrium selection device. We test the prediction of the model in a laboratory experiment in which we allowed participants to declare their income and compare the behavior of participants facing different tax institutions. In the experiment, we compare collusive tax evasion with independent tax evasion when strong and weak social norms are induced. Our main hypothesis cannot be rejected: The tax compliance norm has a stronger negative effect on the magnitude of collusive tax evasion in comparison with it's effect on independent tax evasion. In the experiment, independently filing taxpayers do not respond to the norm, whereas collusively evading individuals react to the norm with substantially higher tax compliance.

In line with the experimental evidence, there is also some cross-country evidence that shows that tax compliance norms and collusive tax evasion are positively correlated. For member countries of the European Union, Figure 1 demonstrates the positive correlation of the countries' personal norms and collusive tax evasion, indicated by the VAT gap as a share of VAT tax liability. ${ }^{4}$

\footnotetext{
${ }^{4}$ The average personal norm of a country is indicated by the mean of the answers to the question, "Please tell me for each of the following whether you think it can always be justified, never be justified, or something in between ...: Cheating on tax if you have the chance. 1 never - 10 always" taken from the European Values Study 2008 (EVS, 2011). The average gap in VAT revenue 2000-2011 is taken from
} 


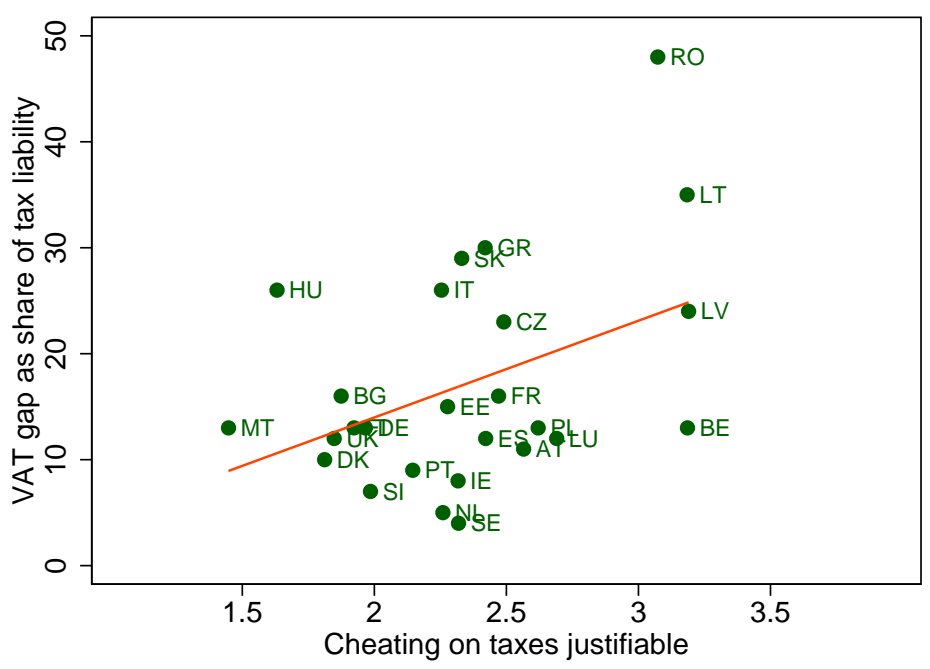

Figure 1: Personal tax compliance norm and VAT fraud

Our result has important tax policy implications. In particular, it implies that the effect of third-party reporting on tax compliance depends not only on audit policies but also strongly on the prevalent tax compliance norm. In other words, the highly positive effect of third-party reporting, Kleven, Knudsen, Kreiner, Pedersen, and Saez (2011) found for Denmark, may not occur in other countries where the tax compliance norm is weak and taxpayers are more willing to evade taxes collusively and to engage in shadow economy activities.

The paper is organized as follows. Employing a simple non-cooperative game-theoretic framework, Section 2 compares the outcome of collusive tax evasion with the standard model of independent tax evasion and derives the main hypothesis on the differential effects of social norms on the magnitude of tax evasion under collusive and independent tax evasion. Section 3 describes the test of this hypothesis through a laboratory experiment. After describing the design of the experiment in detail, results are presented. Section 4 presents the conclusions.

Table 3.1.1 in CPB Netherlands Bureau for Economic Policy Analysis (2013). 


\section{Two simple games}

We consider two simple public good games with rule-based punishment for non-compliance, and both are framed as tax evasion games. The first game is the standard tax evasion game in which each individual declares his or her income and is taxed and - in case of detected tax evasion - punished accordingly. In the second game, third-party reporting is introduced such that tax payments and fines also depend on the tax declaration of a second individual. This section describes the two games and - assuming expected utility maximization and risk neutrality - the respective Nash equilibria. We apply a non-cooperative game-theoretic concept because we consider binding contracts on illegal behavior to be impossible.

In both games, there are $n$ players, where $n$ is an even number, with gross income $y_{1}, \ldots, y_{n}$. By the choice of declared income, $y_{i}^{d}$, each player maximizes expected payoffs

$$
E\left[y_{i}\right]=p y_{i}^{c}+(1-p) y_{i}^{n},
$$

where $p$ is the exogenously determined audit probability, $y_{i}^{c}$ is the net income if the tax evader is convicted, and $y_{i}^{n}$ is the net income if tax evasion is not detected. Excluding tax rebates, we assume $y_{i}^{d} \geq 0$. Reflecting the benefits and costs of a public good, income depends positively on aggregate tax revenue, but negatively on individual tax payments.

\subsection{Independent tax evasion}

In the independent tax evasion game, declared income is taxed at rate $t$. Not-declared income is taxed at the higher tax rate $\tau$, with $\tau>t$, if the tax file is audited and tax evasion is detected. Regular tax payments are multiplied by a multiplier $\lambda$, and a lumpsum is redistributed to taxpayers with $1<\lambda<n .{ }^{5}$ To capture administrative audit costs, we assume that revenues from fines do not affect taxpayers directly. Hence, net income, $y_{i}^{n}$ and $y_{i}^{c}$, and transfers from regular tax payments, $g$, are

$$
\begin{aligned}
y_{i}^{n} & =y_{i}-t y_{i}^{d}+g, \\
y_{i}^{c} & =y_{i}^{n}-\tau\left(y_{i}-y_{i}^{d}\right), \\
g & =\sum_{i=1}^{n} t y_{i}^{d} \lambda / n .
\end{aligned}
$$

\footnotetext{
${ }^{5}$ The multiplier $\lambda$ implicitly captures the specific benefits of public expenditure.
} 
Because $d E\left[y_{i}\right] / d y_{i}^{d}=(\lambda / n-1) t+p \tau, y_{i}^{d}=0$ is a dominant strategy for taxpayer $i$ if $1-\lambda / n-p \tau / t$ is greater than zero. The term $1-\lambda / n-p \tau / t$ measures the expected costs of one tax dollar from the individual taxpayers point of view. These costs are lower than 1 because a fraction of any tax dollar, $\lambda / n$, is revalued and redistributed back to the respective taxpayer, and any dollar paid in taxes reduces the expected fines by $p \tau / t$. Hence, the following proposition holds.

Proposition 1 If $1-\lambda / n-p \tau / t>0$, the independent tax evasion game has a unique Nash equilibrium, where $y_{i}^{d}=0, i=1, \ldots, n$.

\subsection{Collusive tax evasion}

In the collusive tax evasion game, the set of taxpayers is divided into $n / 2$ pairs of players. Each taxpayer observes his or her partner's true income. Although he or she files independently, declarations are interrelated. Any declaration by a taxpayer also reveals something about the true income of his or her partner to the tax authorities. To model this interdependence in a stylized way, we assume that the effectively declared income is equal to the true income times the maximum individual declaration rate of the two partners. Thus, for taxpayer $i$ paired with taxpayer $j, j \neq i$, effectively declared income, $y_{i}^{e}$, net income without and with an audit, $y_{i}^{n}$ and $y_{i}^{c}$, and transfers from regular tax payments, $g$, are

$$
\begin{aligned}
y_{i}^{e} & =\max \left\{\frac{y_{i}^{d}}{y_{i}}, \frac{y_{j}^{d}}{y_{j}}\right\} y_{i} \\
y_{i}^{n} & =y_{i}-t y_{i}^{e}+g, \\
y_{i}^{c} & =y_{i}^{n}-\tau\left(y_{i}-y_{i}^{e}\right), \\
g & =\sum_{k=1}^{n} t y_{k}^{e} \lambda / n .
\end{aligned}
$$

In the collusive tax evasion game, third-party reporting effectively limits tax evasion. Tax evasion without the partner's consent is impossible, but both partners can collusively evade taxes. 
If $y_{i}^{d} / y_{i} \leq y_{j}^{d} / y_{j}$, the marginal effect of individual declaration is equal to

$$
\frac{d E\left[y_{i}\right]}{d y_{i}^{d}}=0
$$

and if $y_{i}^{d} / y_{i}>y_{j}^{d} / y_{j}$, the marginal effect is equal to

$$
\frac{d E\left[y_{i}\right]}{d y_{i}^{d}}=-t+p \tau+\frac{\lambda}{n} t\left(1+\frac{y_{j}}{y_{i}}\right) .
$$

The marginal effect according to Equation (5) is by $t\left(y_{j} / y_{i}\right) \lambda / n$ larger than the marginal effect in the independent tax evasion game. This additional positive term captures the fact that any additionally declared dollar increases the partner's tax payments and, thus, the tax rebate. However, if $1-\lambda / n-p \tau / t>\left(y_{j} / y_{i}\right)(\lambda / n)$, the marginal effect, Equation (5), is negative and thus, the taxpayer has no incentive to declare more than his or her partner. However, even then, tax evasion is no longer a dominant strategy for all taxpayers because a taxpayer is indifferent between those levels of his or her own declaration that do not exceed the level of declaration of his or her partner. The next proposition describes the multiple equilibria that arise from this game.

Proposition 2 If $1-\lambda / n-p \tau / t>\left(y_{j} / y_{i}\right)(\lambda / n)$, for all paired taxpayers $i$ and $j$, the collusive tax evasion game has multiple Nash equilibria, where $y_{i}^{d} / y_{i}=y_{j}^{d} / y_{j}$ holds for all paired taxpayers $i$ and $j$.

Because the individual declaration has no effect on the taxpayer's payoff if the taxpayer declares no more than his or her partner, any combination of declarations where both partners declare the same fraction of income is an equilibrium provided that taxpayers do not benefit from declaring more than their partners, i.e., provided that Equation (5) is negative. If $y_{i}^{d} / y_{i}>y_{j}^{d} / y_{j}$, taxpayer $i$ affects his or her partner $j$ 's expected utility because

$$
\frac{d E\left[y_{j}\right]}{d y_{i}^{d}}=(-t+p \tau) \frac{y_{j}}{y_{i}}+\frac{\lambda}{n} t\left(1+\frac{y_{j}}{y_{i}}\right) .
$$

If taxpayer $i$ declares more, this raises the tax liability of taxpayer $j$, reduces his or her expected fine, and increases the benefit from the public good. If the regular tax rate, $t$, is sufficiently large, the external effect is negative. ${ }^{6}$

\footnotetext{
${ }^{6}$ Alternatively, we could have assumed that the effectively declared income is equal to the individually
} 
If the marginal effect, Equation (5), were positive, the respective taxpayer would declare his or her income completely. In equilibrium, his or her partner for whom Equation (5) is negative could select any declaration rate between 0 and 1 . Moreover, all pairs for whom Equation (5) is negative for both partners select their declaration rates to fulfill $y_{i}^{d} / y_{i}=y_{j}^{d} / y_{j}$ as described in Proposition 2.

\subsection{Independent tax evasion, collusive tax evasion, and social norms}

In both games, a strict tax compliance norm reduces tax evasion if it changes the payoff functions of taxpayers accordingly. However, to have an effect on outcomes, in the collusive tax evasion game, social norms do not need to change payoff functions. Social norms may simply act as an equilibrium selection device. In particular, a more broadly accepted social compliance norm may lead to higher tax compliance.

As mentioned above, based on Coleman (1987) and Elster (1989), we define social norms as commonly shared guidelines about appropriate and accepted behavior in a specific situation: in this case, a situation with the opportunity to evade taxes. A stricter norm for tax compliance implies less acceptance of deviant behavior - evasion - in the norm-holding group. Given that (tax compliance) norms also shape expectations about the share of compliant and deviant behavior in the group, a stricter tax compliance norm decreases the expected share of evasion. The share of non-compliant behavior is crucial in collusive tax reporting, as evasion is only possible if all involved partners agree. A stricter norm decreases the expectation to meet another deviant person. The norm informs about the behavior of others and can be used as focal point for equilibrium selection. A stricter norm leads to less evasion offers independently of the internalized norm of the person. In individual tax reporting, however, the decision is independent of others' decision and is not observable for them. Only the internalized compliance norm of the actor influences the tax reporting decision. Expectations about others' behavior that depend on the compliance norm of the declared income and that the penalty is affected by the difference in the taxpayer's and his or her partner's declared income. This implies that an increase in the declaration rate of a certain taxpayer has mainly a negative effect on the partner because it increases the penalty the partner faces. 
group are not considered. Because the tax compliance norm affects the outcome in the independent tax evasion game only if it changes payoff functions, social norms should have a stronger positive effect on tax compliance if third-party reporting requires collusion. This is exactly the main hypothesis of this paper as stated below.

Hypothesis The need for collusion under third-party reporting increases the positive effect of a stricter compliance norm on tax compliance.

\section{Experiment}

To test our hypothesis, we conducted a one-shot experiment in 2013/2014 at LERN (Laboratory for Experimental Research Nuremberg) with 224 students. $^{7}$ The sample includes $53 \%$ females and ranges in age from 19 to 32 with median of 23 . Of the participants, $33 \%$ study economics, $28 \%$ business administration, $11 \%$ business education, $10 \%$ socioeconomics, and $2 \%$ business informatics, and $17 \%$ are enrolled in other study programs. $48 \%$ of the participants have some experience with tax filing, and $39 \%$ consider themselves risk seekers.

For our experiment, we employed a tax frame. As norms are context-based, we consider a tax frame appropriate to test the strictness of tax compliance norms. ${ }^{8}$. As almost half of our participants already had experiences with tax filing, it is a reasonable assumption that the participants could cope with the tax framing. Using statements on the attitude of the general public towards tax evasion, we induced either a strict or a weak tax compliance norm at the beginning of the experiment. Because we are primarily interested in the effect of norms on independent and collusive tax evasion rather than the evolution of social norms (see, e.g., Fortin, Lacroix, and Villeval, 2007), we simply induced norms by exogenously

\footnotetext{
${ }^{7}$ Subsection 3.1 describes the experiment in detail.

${ }^{8}$ The use of framed language is wildly discussed and tested in experimental economics with contradicting results (for an overview and methodological contribution to the discussion, see Abbink and Hennig-Schmidt, 2006) Of particular interest for our study is the finding of Ellingsen, Johannesson, Mollerstromb, and Munkhammar (2012) that social frames enter people's beliefs rather than their preferences and are therefore coordination devices, which is perfectly consistent with our reasoning.
} 
given statements taken from two different surveys conducted in Germany. ${ }^{9}$ In combination with randomly assigned tax institutions, the sample was divided into four equally sized groups: $25 \%$ of the participants were assigned to the collusive tax evasion game with the strict compliance norm, $25 \%$ of the participants were assigned to the collusive tax evasion game with the weak compliance norm, $25 \%$ of the participants played the independent tax evasion game under the strict compliance norm, the remaining $25 \%$ of participants played the independent tax evasion game under the weak compliance norm. For all participants, group size in the game, $n$, was 4 , and the true income of all participants was 100; in the collusive tax evasion game, participants were randomly paired (such that each group consists of 2 pairs). From the statements of the participants, we calculated the planned concealed income $e_{i}=y_{i}-y_{i}^{d}$ for each individual. To test our hypothesis, we analyzed

$$
\begin{aligned}
e_{i}=\beta_{0} & +\beta_{1} \text { collusion }+\beta_{2} \text { strictnorm }+\beta_{3} \text { collusion } \times \text { strictnorm } \\
& +\sum_{j} \beta_{j} X_{j}+\epsilon_{i},
\end{aligned}
$$

where $X_{j}$ are control variables included in some but not all specifications, collusion is a dummy variable that indicates participation in the collusive tax evasion game, and strictnorm is a dummy variable that indicates the strict compliance norm. Our hypothesis implies that the coefficient of the interaction term, $\beta_{3}$, i.e., the average treatment effect (on the treated), is negative.

\subsection{Experimental Proceeding}

The experiment was programmed and conducted with the experiment software z-Tree (Fischbacher, 2007); participants were recruited with ORSEE (Greiner, 2004). Eight sessions were conducted on four different days. The timing of the sessions prevented communication between the participants. After the participants arrived and were seated randomly, instructions were handed out and read aloud to make sure all participants had common knowledge about the proceedings of the experiment. The understanding of the experiment was tested with a quiz after the instructions (see the instructions and quiz in the

\footnotetext{
${ }^{9}$ Compared to implementing social norms in a separate game, our strategy does not suffer from any interaction between the norm creating game and the game of interest.
} 
Appendix). ${ }^{10}$

The instructions informed the participants about the tax rate on income $(t=0.4)$, the audit probability $(p=0.2)$ and the fine rate on concealed income $(\tau=0.6)$. The calculation of net income as well as the calculation of the repayment from redistribution were explained. Instructions and the experiment itself used taxation language.

At the beginning of the experiment, the participants were divided into groups of four. The members of the groups were anonymous, i.e., there was no opportunity to identify the members of the group during or after the experiment. In the first stage of both the individual and the collusive treatments, the norm was induced. ${ }^{11}$ First, the participants received general information about taxation (see Appendix). Then, the norm was operationalized as a statement that summed up a survey of tax compliance behavior. In the weak norm treatment, it was stated, "A representative survey by the Allensbach Institute showed that a large majority of people do not consider tax evasion as a crime: over $53 \%$ of the participants consider it acceptable to evade taxes if the opportunity arises." ${ }^{12}$ In the strict norm treatment, the statement said, "A representative survey by Infratest showed that a large majority of people reject the evasion of taxes: over $87 \%$ do not consider incorrect statements in tax declarations acceptable." 13 The statement was shown on a single screen with no possibility to skip. After the participants received their income in the next stage, they had to file their income.

In the independent tax evasion game, the declared income was subject to taxes. After the participants declared their income, they received information on their tax payment, whether they were audited and fined, their net income after taxes, and possible fines and the lump-sum redistributed in groups of four. Tax payments were calculated as declared income $\times 0.4$; possible fines were applied on concealed income, i.e., (actual income declared income $) \times 0.6$; net income was calculated as actual income - tax payments possible fine. All regular tax payments of the four group members were summed, multiplied by $\lambda=1.5$ and then distributed equally to the four group members. The experiment ended,

\footnotetext{
${ }^{10}$ The original German versions of the instructions and quiz are available upon request.

${ }^{11}$ Tests of whether norms have been induced successfully are described in more detail in subsection 3.2.

${ }^{12}$ Institut für Demoskopie Allensbach (2001)

${ }^{13}$ Stiftung Marktwirtschaft (2010), figure 4.5, p. 7.
} 
and a final questionnaire had to be answered before the payoffs were distributed.

In the collusive tax evasion game, the participants within the groups were randomly matched in teams of two. The teams were anonymous as well as the groups. After receiving information about their own and their partner's incomes, participants had to declare their individual income. Then, the participants were informed about the decision of their partners and about the actual taxed income. The actual taxed income is calculated as $\max \left\{y_{i}^{d} / y_{i}, y_{j}^{d} / y_{j}\right\} y_{i}$. As discussed in more detail in Section 2.2, this formula reflects the fact that any declaration by a taxpayer partially reveals the true income of his or her partner. It implies that individually planned evasion and effective evasion can differ. Aside from this additional information, the experiment proceeded in the same way as the individual treatment. ${ }^{14}$

To avoid reputation building and neglect of the norm, which we induced in the beginning, the experiment lasted only one round.

The questionnaire consisted of questions on age, gender, the study program, experience with tax filing, attitudes towards taxation, and risk behavior.

At the end of the experiment, payoffs in ECU were converted to Euros at the exchange rate $10 \mathrm{ECU}=1$ Euro, and the show-up fee of 2.50 Euro was added. Final payoffs were paid out anonymously one at a time as the participants left the laboratory.

\subsection{Results}

First, confirming the large experimental literature, the simple rational tax evader model without any reference to social norms is rejected. On average, taxpayers intend to evade only $34.53 \%$ of their income, $38.25 \%$ if they act independently and $30.81 \%$ if they collude. Taking risk aversion into consideration, these numbers are still not fully consistent with the simple rational tax evader model.

Second, to test whether we successfully induced the compliance norm, we compared the answers to three questions on tax evasion in the two treatment groups of strict and weak compliance norms (see the Appendix). First, having read the weak compliance norm

\footnotetext{
${ }^{14}$ To establish comparative pecuniary incentives, the multiplier, $\lambda$, in the collusive tax evasion game was slightly lower than in the independent tax evasion game (1.2 rather than 1.5).
} 
statement, participants estimated on average that $49.54 \%$ of German taxpayers have deliberately filed incorrectly, whereas participants who had read the strong compliance norm statement estimated on average that only $40.01 \%$ of German taxpayers have cheated. The difference is statistically significant at the $1 \%$ level. The answers to the second question of whether German taxpayers consider incorrect filing acceptable were also statistically significantly different. Putting a metric interpretation on the ordinal 5-point Likert scale under the weak compliance norm, the average degree of approval was 3.27; under the strong compliance norm, it was only 2.51. The answers to the third question of whether participants personally consider cheating acceptable provide similar and statistically significant results. Under the weak compliance norm, the average degree of approval was 2.35; under the strong compliance norm, it was only 2.02. Hence, we can be relatively sure that the opening statements induced different social norms successfully. Moreover, the results indicate that the induced norm shapes beliefs about the behavior of others more strictly than own internalized norms. The ratings for the last question are lower in both groups, and the difference - the treatment effect - is smaller compared to the second question on general norms.

Third, we compared the average planned evasion across groups. The results shown in Table 1 are in line with our hypothesis. Under the strict compliance norm and in the collusive tax evasion game, the participants evaded significantly less than in any other environment (significant at the $1 \%$ and the $5 \%$ level, respectively), but the strict norm has no statistically significant effect in the independent tax evasion game. ${ }^{15}$ The difference in difference has the predicted negative sign and is of large magnitude, namely, $-18.339=$ $(24.286-37.339)-(40.893-35.607)$.

Regression analysis also allows us to conclude that we cannot reject our hypothesis. Table 2 shows the regression results with and without additional control variables. The coefficient of the interaction term is statistically significant independent of whether control variables are included. The stricter norm reduced the concealed income by 15-18 percentage points (= Euros) more than under independent tax evasion. Column (1) shows the results

\footnotetext{
${ }^{15} \mathrm{~A}$ Wilcoxon rank-sum (Mann-Whitney-U) test also shows that the strict compliance norm has a statistically significant effect on the collusive tax evasion game (at the $5 \%$ level), but not on the independent tax evasion game.
} 


\begin{tabular}{ccc} 
Treatment & Mean & Std. Dev. \\
\hline collusion $=0$, strictnorm $=0$ & 35.607 & 33.935 \\
collusion $=0$, strictnorm $=1$ & 40.893 & 38.953 \\
collusion $=1$, strictnorm $=0$ & 37.339 & 34.939 \\
collusion $=1$, strictnorm $=1$ & 24.286 & 33.241 \\
\hline
\end{tabular}

Table 1: Planned evasion

without controls, and column (2) also includes gender, age, experience with filing, and risk attitude as controls. ${ }^{16}$

In addition to the interaction term, only gender is statistically significant. Women evaded significantly less than men. This result is in line with other public good experiments, as shown in an overview by Croson and Gneezy (2009), although there is also evidence of an opposing direction of the gender difference. However, the result is not surprising when considering the gender difference in criminal activities, as is tax evasion. There is broad evidence that women commit fewer offenses than men (for a good overview, see, e.g., Mears, Ploeger, and Warr, 1998). Explanations for this gender gap in criminal behavior include peer influence, as stated by Sutherland, Cressey, and Luckenbill (1992), or a theory of moral evaluation (Gilligan, 1982). ${ }^{17}$ In our case, women's tendencies to care more for others (Gilligan, 1982) and their more context-dependent evaluation of situations (Croson and Gneezy, 2009) seem to provide a good explanation of the observed differences.

Figure 2 shows that participants tended to the extremes. Many participants evaded either nothing or everything. However, the effect is more pronounced at the lower (honest) end of the distribution. Furthermore, the strict norm was effective in the collusive tax evasion game, whereas it had no or even an adverse (but not significant) effect in the independent tax evasion game.

Finally, by splitting our sample, we found that the differential norm effect was highly gender-specific. First, the F-statistic of our basic regression and additional regressions indi-

\footnotetext{
${ }^{16}$ Because study programs were unevenly distributed across treatment groups, with no effect on statistical significance and little effect on coefficients, we also ran regressions where we controlled for study programs.

${ }^{17}$ Mears, Ploeger, and Warr (1998) provide an empirical test of those theories that conclude that both approaches seem to go hand in hand.
} 
(1)

\begin{tabular}{lcc}
\hline collusion & 1.732 & 2.622 \\
& $(6.509)$ & $(6.227)$ \\
strict norm & 5.286 & 4.312 \\
& $(6.904)$ & $(6.542)$ \\
collusion x strict norm & $-18.34^{*}$ & $-14.98^{*}$ \\
& $(9.444)$ & $(9.021)$ \\
female & & $-23.35^{* * *}$ \\
& & $(4.931)$ \\
age & 0.519 \\
& & $(0.846)$ \\
experience with filing & -1.134 \\
& & $(4.640)$ \\
risk-loving & & 3.120 \\
& $35.61^{* * *}$ & $(2.415)$ \\
Constant & $(4.535)$ & 26.28 \\
& 2.391 & $(20.83)$ \\
$\mathrm{F}$ & 0.0305 & 6.679 \\
$\mathrm{R}^{2}$ & 0.0173 & 0.162 \\
$\mathrm{R}_{a}^{2}$ & 224 & 0.135 \\
Observations & 222 \\
\hline Robust standard errors in parentheses, ${ }^{* * *} \mathrm{p}<0.01, * * \mathrm{p}<0.05,{ }^{*} \mathrm{p}<0.1$
\end{tabular}

Table 2: OLS estimations of planned concealed income

\begin{tabular}{lcccc} 
& (women) & (men) & (women) & (men) \\
\hline collusion & 4.243 & 0.913 & 7.054 & 2.082 \\
& $(7.429)$ & $(9.733)$ & $(7.409)$ & $(9.877)$ \\
strict norm & 3.074 & 7.345 & 4.097 & 6.613 \\
& $(6.928)$ & $(10.65)$ & $(6.471)$ & $(11.18)$ \\
collusion x strict norm & -14.94 & -16.09 & $-15.79^{*}$ & -14.78 \\
& $(9.809)$ & $(15.74)$ & $(9.421)$ & $(16.44)$ \\
age & & & 1.419 & -1.323 \\
& & & $(0.942)$ & $(1.868)$ \\
experience with filing & & & -5.564 & 6.364 \\
& & & $(4.577)$ & $(8.791)$ \\
risk-loving & & & $(2.476)$ & -2.323 \\
& $22.48^{* * *}$ & $47.83^{* * *}$ & -29.51 & $81.81^{*}$ \\
Constant & $(4.343)$ & $(7.124)$ & $(21.54)$ & $(43.73)$ \\
& 1.609 & 0.506 & 3.829 & 0.397 \\
$\mathrm{~F}$ & 0.0347 & 0.0172 & 0.138 & 0.0241 \\
$\mathrm{R}^{2}$ & 0.00928 & -0.0117 & 0.0916 & -0.0363 \\
$\mathrm{R}_{a}^{2}$ & 118 & 106 & 118 & 104 \\
Observations & & & \\
\hline Robust standard errors in parentheses, ${ }^{* * *} \mathrm{p}<0.01,{ }^{* *} \mathrm{p}<0.05,{ }^{*} \mathrm{p}<0.1$
\end{tabular}

Table 3: OLS estimations of planned concealed income by gender 


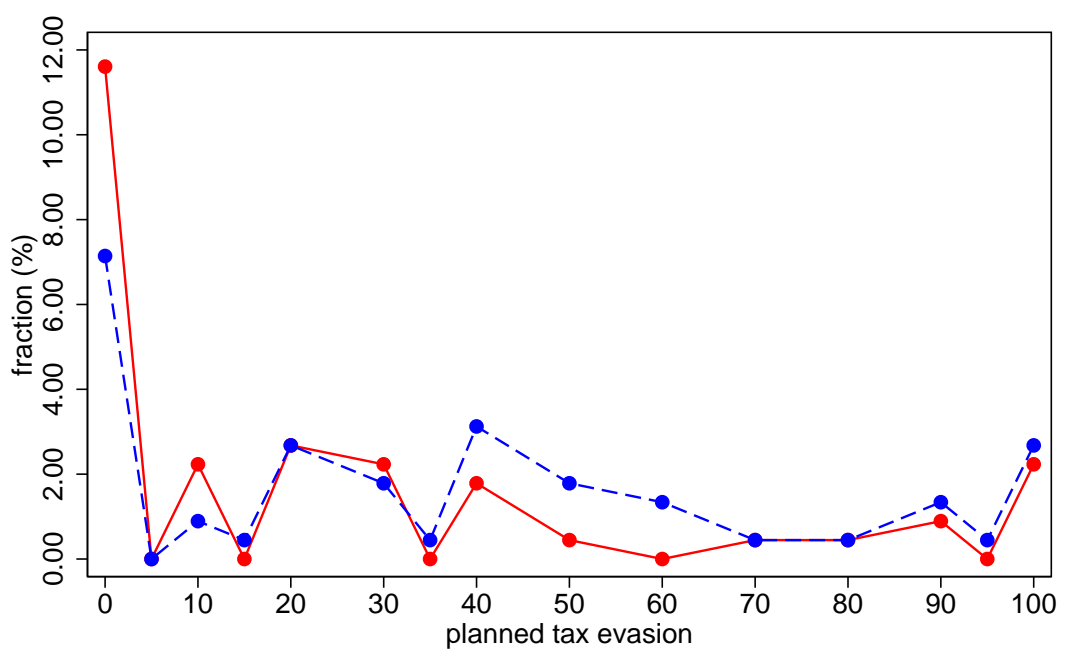

collusive tax evasion

- - - - weak compliance norm $\_$strict compliance norm

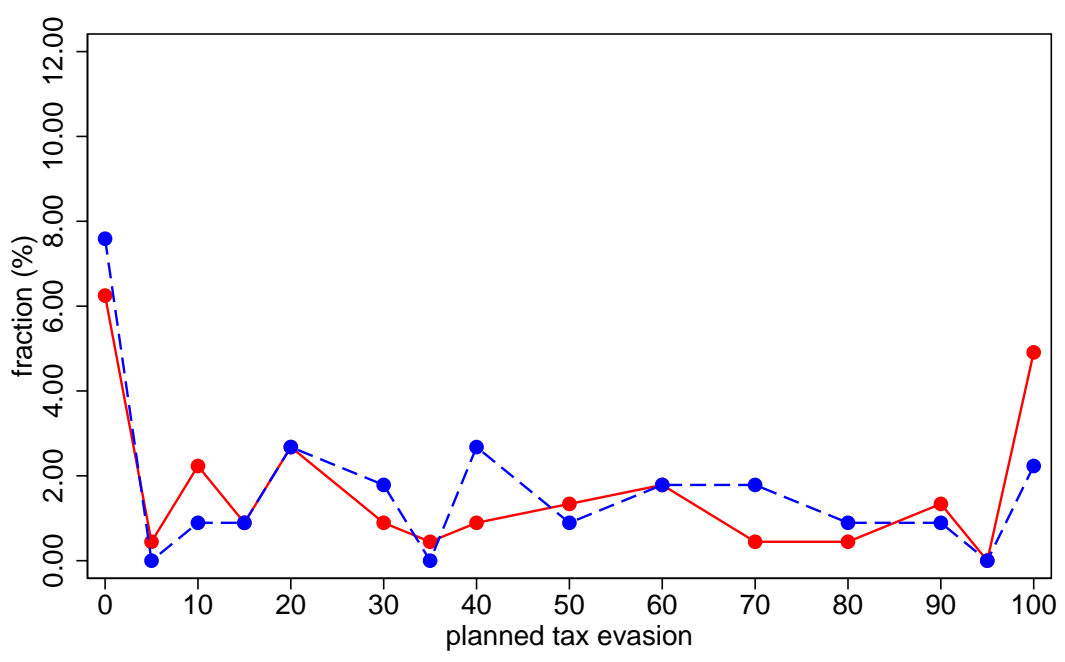

independent tax evasion

- - - - weak compliance norm $\longrightarrow$ strict compliance norm

Figure 2: Tax evasion, norms, and institutions 
cated that we must include control variables, particularly individual risk attitude. Second, the behavior of women was sensitive to the stated social norm provided that we control for their individual risk attitude, whereas the behavior of men was not (see Table 3). However, statements on norms changed not only women's perceptions but also men's perceptions of tax evasion. Although slightly less significantly, when confronted with the strict compliance statement, men also expected more tax evasion and less acceptance than after reading the weak compliance statement. The fact that according to the F-statistic, the behavior of men cannot be explained at all by the right-hand side variables in these regressions may indicate that men were not sufficiently affected by the tax framing. This results confirms the conclusion by (Croson and Gneezy, 2009, p. 463) "that women are more sensitive to ... the experimental context than are men."

\section{Concluding remarks}

This paper showed theoretically and empirically that the tax compliance norm has a stronger negative effect on the magnitude of collusive tax evasion in comparison with its effect on independent tax evasion. Our result has important implications for the assessment of deterrence mechanisms. First, the magnitude of the positive effects of third-party reporting and withholding taxes on overall tax compliance depends on the strictness of tax compliance norms. Second, the external validity of research on third-party reporting and withholding taxes is limited to countries with similar social norms. Third, policy measures such as anti-corruption policies that increase the tax morale may have strong positive effects on tax revenue even in countries where third-party reporting is widely used. Fourth, women tend to respond better to policy measures that enforce cooperation by emphasizing the social importance of taxation and the social disapproval of delinquent behavior. Especially in countries with the already high or rising social and economic participation of women, these measures can strengthen compliance.

Focusing on the equilibrium-selection function of social norms, this paper did not examine how norms evolve. In particular, it did not consider the impact of institutions such as third-party reporting and withholding taxes on the evolution of tax compliance norms. This question is left for future research. 
Acknowledgements We gratefully acknowledge the financial support from the FAUs Emerging Fields Initiative (University of Erlangen-Nuremberg). For providing the laboratory resources used in this study, we kindly thank LERN of the University of ErlangenNuremberg. The paper was presented at the Bavarian Public Economics Seminar 2014 in Munich and at the University of Rostock. The comments of the participants, especially Thiess Büttner, are appreciated with gratitude. 


\section{References}

Abbink, K., And H. Hennig-Schmidt (2006): "Neutral versus loaded instructions in a bribery experiment," Experimental Economics, 9, 103-121.

Allingham, M. G., and A. Sandmo (1972): "Income tax evasion: A theoretical analysis," Journal of Public Economics, 1, 323-338.

Alm, J. (2012): "Measuring, explaining, and controlling tax evasion: Lessons from theory, experiments, and field studies," International Tax and Public Finance, 19, 54-77.

Alm, J., J. Deskins, And M. McKee (2009): "Do individuals comply on income not reported by their employer?," Public Finance Review, 37, 120-141.

Alm, J., G. H. McClelland, And W. D. Schulze (1992): "Why do people pay taxes?," Journal of Public Economics, 48, 21-38.

Alm, J., And B. Torgler (2006): "Culture differences and tax morale in the United States and in Europe," Journal of Economic Psychology, 27, 224-246.

Andreoni, J., B. Erard, And J. Feinstein (1998): "Tax compliance," Journal of Economic Literature, 36, 818-860.

Boadway, R., N. Marceau, and S. Mongrain (2002): "Joint tax evasion," Canadian Journal of Economics, 35, 417-435.

Chang, J.-J., And C.-C. LAi (2004): "Collaborative tax evasion and social norms: Why deterrence does not work," Oxford Economic Papers, 56, 344-368.

Chetty, R. (2009): "Is the taxable income elasticity sufficient to calculate deadweight loss? The implications of evasion and avoidance," American Economic Journal: Economic Policy, 1, 31-52.

Coleman, J. (1987): "Norms as social capital," in Economic imperialism: The economic approach applied outside the field of economics, ed. by G. Radnitzky, and P. Bernholz. Paragon, New York. 
CPB Netherlands Bureau for Economic Policy Analysis (2013): "Study to quantify and analyse the VAT Gap in the EU-27 Member States Final Report," TAXUD/2012/DE/316, FWC No. TAXUD/2010/CC/104.

Croson, R., And U. Gneezy (2009): "Gender differences in preferences," Journal of Economic Literature, 47, 448-474.

Dwenger, N., H. Kleven, I. Rasul, And J. Rincke (2014): "Extrinsic and intrinsic motivations for tax compliance: Evidence from a field experiment in Germany," Working paper.

Ellingsen, T., M. Johannesson, J. Mollerstromb, and S. Munkhammar (2012): "Social framing effects: Preferences or beliefs?," Games and Economic Behavior, 76, $117-130$.

ElSter, J. (1989): "Social norms and economic theory," Journal of Economic Perspectives, 3, 99-117.

EVS (2011): "European Values Study 2008: Integrated Dataset (EVS 2008)," ZA4800 Data file Version 3.0.0, GESIS Data Archive, Cologne.

Feld, L., And C. LARSEn (2012): Undeclared work, deterrence and social norms: The case of Germany. Springer-Verlag, Berlin Heidelberg.

FischBACHER, U. (2007): "z-Tree: Zurich toolbox for ready-made economic experiments," Experimental Economics, 10, 171-178.

Fortin, B., G. Lacroix, and M.-C. Villeval (2007): "Tax evasion and social interactions," Journal of Public Economics, 91, 2089-2112.

Gilligan, C. (1982): In a different voice: Psychological theory and women's development. Harvard University Press, Cambridge, MA.

Gordon, J. P. F. (1989): "Individual morality and reputation costs as deterrents to tax evasion," European Economic Review, 33, 797-805. 
GREINER, B. (2004): "The online recruitment system ORSEE 2.0 - A guide for the organization of experiments in economics," Working Paper Series in Economics 10, University of Cologne.

Institut für Demoskopie Allensbach (2001): "Moral 2001 - Werte und Normen im Wandel," Allensbacher Berichte 10.

Klepper, S., AND D. NAGin (1989): "The anatomy of tax evasion," Journal of Law, Economics, and Organization, 5, 1-24.

Kleven, H., C. Kreiner, and E. Saez (2009): "Why can modern governments tax so much? An agency model of firms as fiscal intermediaries," NBER Working Paper 15218.

Kleven, H. J., M. B. Knudsen, C. T. Kreiner, S. Pedersen, and E. Saez (2011): "Unwilling or unable to cheat? Evidence from a tax audit experiment in Denmark," Econometrica, 79, 651-692.

Kumler, T., E. Verhoogen, and J. Frias (2013): "Enlisting employees in improving payroll-tax compliance: Evidence from Mexico," CDEP-CGEG Working Paper 7.

Mears, D. P., M. Ploeger, and M. Warr (1998): "Explaining the gender gap in delinquency: Peer influence and moral evaluations of behavior," Journal of Research in Crime and Delinquency, 35, 251-266.

Myles, G. D., And R. A. NAylor (1996): "A model of tax evasion with group conformity and social customs," European Journal of Political Economy, 12, 49-66.

Putnam, R. (2001): "Social capital: Measurement and consequences," ISUMA - Canadian Journal of Policy Research, 2, 41-51.

SAez, E. (2010): "Do taxpayers bunch at kink points?" American Economic Journal: Economic Policy, 2, 180-212.

Schneider, F., And D. H. Enste (2000): "Shadow economies: Size, causes, and consequences," Journal of Economic Literature, 38, 77-114. 
Scholz, J., And N. Pinney (1995): "Duty, fear, and tax compliance: The heuristic basis of citizenship behavior," American Journal of Political Science, 39, 490-512.

Slemrod, J. (2007): "Cheating ourselves: The economics of tax evasion," Journal of Economic Perspectives, 21, 25-48.

Slemrod, J., M. Blumenthal, and C. Christian (2001): "Taxpayer response to an increased probability of audit: Evidence from a controlled experiment in Minnesota," Journal of Public Economics, 79, 455-483.

Stiftung MarkTwiRTschaft (2010): "Hintergrundinformationen zum Pressegespräch der Stiftung Marktwirtschaft - Guter Staat - Böse Bürger? Schattenwirtschaft und Steuerhinterziehung," Discussion paper.

Sutherland, E. H., D. R. Cressey, and D. F. Luckenbill (1992): Principles of criminology. Lippincott., Philadelphia, 11th edn.

Traxler, C. (2010): "Social norms and conditional cooperative taxpayers," European Journal of Political Economy, 26, 89-103.

Wrede, M. (1993): Ökonomische Theorie des Steuerentzuges: Steuervermeidung, -umgehung und -hinterziehung. Physica-Verlag.

YAnIV, G. (1992): "Collaborated employee-employer tax evasion," Public Finance, 47, $312-321$

(1998): "Tax evasion by misinforming withholding agents," Public Finance Review, 26, 362-375.

Young, H. (2008): "Social norms," in The New Palgrave Dictionary of Economics, ed. by S. N. Durlauf, and L. E. Blume, no. 7, pp. 647-651. Palgrave Macmillan, Basingstoke. 


\section{Appendix}

\section{General information about taxation}

Before we start the experiment, we put together some information on taxes for you. Please read it thoroughly:

- Everyone who is subject to taxes according to the tax law has to pay taxes.

- There are three main tax functions: financing the public budget, correcting externalities and redistributing wealth and income.

- The intentional evasion of taxes is a criminal offense and can be punished, e.g., with fines.

\section{Instructions in the independent tax evasion game}

\section{Welcome to this experiment!}

You are participating in an experiment on taxation. You receive a show-up fee of 2.50 Euro. Depending on your decisions and the decisions of the other participants, you can earn more money. All income you generate during the experiment will be paid to you after the experiment (including the 2.50 Euro show-up fee). The payment is anonymous, i.e., no other participant will be informed about your payment.

In the experiment, the currency "ECU" is used. Your generated income is going to be converted into Euro and paid to you in cash.

The exchange rate is $10 \mathrm{ECU}=1$ Euro.

During the experiment, communication with other participants is prohibited. Please, turn off your phones.

If questions on the instructions or anything else during the experiment arise, please raise your hand. One of the experimenters will answer your question.

We want to note that there are no correct or incorrect decisions in the experiment. Decide according to your preferences. 
General information: The experiment lasts one round. The participants of the experiment are split up into groups of four. The other members of your group are anonymous, i.e., you have no information during or after the experiment about who is a member of your group. Your income depends on your own decisions and the decisions of your group members.

Course of the experiment: The experiment consists of several stages:

1) At the beginning, you receive a one-time income. At that time, only you know how high your income is. The income is subject to tax at a rate of $40 \%$.

2) To determine your tax payment, you have to declare your income.

Your tax payment is calculated as follows:

tax payment $=$ declared income $\times 0.4$

3) With a probability of $20 \%$, you are audited. If it turns out you have not declared your actual income, the share of your income you did not declare is subject to a higher tax at a rate of $60 \%$.

Your additional payment in case of an audit is calculated as follows:

additional payment $=($ actual income - declared income $) \times 0.6$

With a probability of $80 \%$, your declaration is not audited and you do not have to pay additional payments.

Example 1

Your actual income is 100 ECU, and you declare an income of 70 ECU. You are audited. Your additional payment: $(100 \mathrm{ECU}-70 \mathrm{ECU}) \times 0.6=30 \mathrm{ECU} \times 0.6=18 \mathrm{ECU}$

Example 2

Your actual income is 100 ECU, and you declare an income of 70 ECU. You are not audited. Your additional payment: 0 ECU

4) Following your regular tax payment and a possible additional payment, your net income is calculated as follows: 
a) if you were audited: net income $=$ actual income - regular tax payment - additional payment

b) if you were not audited: net income $=$ actual income - regular tax payment

Example 3

Your actual income is 100 ECU, and you declared your actual income:

Your regular tax payment $=100 \mathrm{ECU} \times 0.4=40 \mathrm{ECU}$

Your additional payment $=(100 \mathrm{ECU}-100 \mathrm{ECU}) \times 0.6=0 \mathrm{ECU}$

Your net income $=100 \mathrm{ECU}-40 \mathrm{ECU}-0 \mathrm{ECU}=60 \mathrm{ECU}$

Example 4

Your actual income is 100 ECU and your declared 60 ECU:

Your regular tax payment $=60 \mathrm{ECU} \times 0.4=24 \mathrm{ECU}$

Your additional payment in the case of audit $=(100 \mathrm{ECU}-60 \mathrm{ECU}) \times 0.6 \mathrm{ECU}=40$

$\mathrm{ECU} \times 0.6=24 \mathrm{ECU}$

Your net income $=100 \mathrm{ECU}-24 \mathrm{ECU}-24 \mathrm{ECU}=52 \mathrm{ECU}$

Your additional payment in the case of no audit $=0$ ECU

Your net income $=100 \mathrm{ECU}-24 \mathrm{ECU}-0 \mathrm{ECU}=76 \mathrm{ECU}$

5) The regular tax payments of all group members are summed and multiplied by a factor of 1.5. Additional payments are not considered. The generated total tax revenue is redistributed in equal shares to group members.

The total tax revenue is calculated as follows: Total tax revenue in the group $=$ the sum of regular tax payments of group members $\times 1.5$

Your tax rebate is: Tax rebate $=$ total tax revenue of the group $/ 4$

Example 5

The sum of all regular tax payments of your group is 160 ECU.

Total tax revenue $=160 \mathrm{ECU} \times 1.5=240 \mathrm{ECU}$

Your tax rebate $=240 \mathrm{ECU} / 4=60 \mathrm{ECU}$ 
6) Your total income from the experiment is calculated as follows:

Total income $=$ net income + tax rebate

Example 6

Your actual income is 100 ECU and you declared your actual income.

The total tax revenue is 240 ECU:

Your net income $=100 \mathrm{ECU}-40 \mathrm{ECU}=60 \mathrm{ECU}$

Your tax rebate $=240 \mathrm{ECU} / 4=60 \mathrm{ECU}$

Your total income $=60 \mathrm{ECU}+60 \mathrm{ECU}=120 \mathrm{ECU}$ 


\section{Quiz}

Your answers to the quiz have no impact on the course of the experiment or on your income.

1. The experiment lasts several rounds [true/false]

2. Groups consist of four members [true/false]

3. Your income is known to all participants [true/false]

4. Tax rebates are split unequally [true/false]

5. Additional payments are included in the calculation of total tax revenue [true/false]

6. Your income is $100 \mathrm{ECU}$, and you declare an income of $80 \mathrm{ECU}$.

(a) You are audited. Calculate:

Your regular tax payment:

Your additional payment:

Your net income:

(b) You are not audited. Calculate:

Your regular tax payment:

Your additional payment:

Your net income:

7. The sum of all regular tax payments of your group is 120 ECU. Calculate:

- The total tax revenue in your group:

- The tax rebate for the group members:

8. Calculate your total income of the experiment in case you were not audited. Use the results from questions 6 (b) and 7 . Your total income: 


\section{Instructions in the collusive tax evasion game}

\section{Welcome to this experiment!}

You are participating in an experiment on taxation. You receive a show-up fee of 2.50 Euro. Depending on your decisions and the decisions of the other participants, you can earn more money. All income you generate during the experiment will be paid to you after the experiment (including the 2.50 Euro show-up fee). The payment is anonymous, i.e., no other participant will be informed about your payment.

In the experiment, the currency "ECU" is used. Your generated income is going to be converted into Euro and paid to you in cash.

The exchange rate is $10 \mathrm{ECU}=1$ Euro.

During the experiment, communication with other participants is prohibited. Please, turn off your phones.

If questions on the instructions or anything else during the experiment arise, please raise your hand. One of the experimenters will answer your question.

We want to note that there are no correct or incorrect decisions in the experiment. Decide according to your preferences.

General information: The experiment lasts one round. The participants of the experiment are split up into groups of four. The other members of your group are anonymous, i.e., you have no information during or after the experiment about who is a member of your group. At the beginning of the experiment, you are randomly matched with another member of your group. Your partner is anonymous, i.e., you have no information during or after the experiment about who your partner is. Your income depends on your own decisions, the decisions of your partner, and the decisions of your group members.

Course of the experiment: The experiment consists of several stages:

1) At the beginning, you receive a one-time income. At that time, only you and your partner know how high your income is. The income is subject to tax at a rate of $40 \%$. 
2) To determine your tax payment, you have to declare your income.

Your tax payment is calculated as follows:

tax payment $=$ eventually declared income $\times 0.4$

Which income is used as your eventually declared income depends on your and your partner's statements. Depending on your and your partner's statements, two possible situations could arise for the calculation of your tax payment:

a) Both you and your partner declare income that is lower than the respective actual income. In this case, eventually declared income is calculated as follows: the ratio of the declared income to the respective actual income is calculated. The larger share is applied to both actual incomes. The resulting income is considered as eventually declared income for both partners and used for the calculation of the regular tax payments.

Example A

Your income is $100 \mathrm{ECU}$, and your partner's income is $90 \mathrm{ECU}$; you declare an income of 70 ECU, your partner declares an income of 45 ECU. On a percentage basis, you declared $70 \%$ of your actual income, your partner declared $50 \%$ of his actual income. The higher fraction, $70 \%$, is applied to the respective actual income:

Your eventually declared income $=100 \mathrm{ECU} \times 0.7=70 \mathrm{ECU}$

Your partner's eventually declared income $=90 \mathrm{ECU} \times 0.7=63 \mathrm{ECU}$

This implies that for the regular tax payments:

Your regular tax payment $=70 \mathrm{ECU} \times 0.4=28 \mathrm{ECU}$

Your partner's regular tax payment $=63 \mathrm{ECU} \times 0.4=25.2 \mathrm{ECU}$

b) You, your partner, or both of you declare the respective actual income. In this case, the respective actual income is taxed. As a consequence, both of you have to pay taxes on the actual income if at least one of you declares the respective actual income. Eventually declared income is actual income.

Example B

Your income is 100 ECU, and your partner's income is 90 ECU; you declare an income of 100 ECU, and your partner declares an income of 60 ECU. 
Your regular tax payment $=100 \mathrm{ECU} \times 0.4=40 \mathrm{ECU}$

Your partner's regular tax payment $=90 \mathrm{ECU} \times 0.4=36 \mathrm{ECU}$

3) With a probability of $20 \%$, you are audited. If it turns out that your tax payment was not calculated based on your actual income, the eventually undeclared share of your income is subject to a higher tax at the rate of $60 \%$. With a probability of $80 \%$, your declaration is not audited, you do not have to pay additional payments, and you only pay the regular tax payment. Your additional payment in the case of an audit is calculated as follows:

additional payment $=($ actual income - eventually declared income $) \times 0.6$

Example 1

Your actual income is 100 ECU, and you eventually declare an income of 70 ECU. You are audited.

Your additional payment: $(100 \mathrm{ECU}-70 \mathrm{ECU}) \times 0.6=30 \mathrm{ECU} \times 0.6=18 \mathrm{ECU}$

Example 2

Your actual income is 100 ECU, and you eventually declare an income of 70 ECU. You are not audited.

Your additional payment: 0 ECU

4) Based on your regular tax payment and potentially on the additional payment, your net income is calculated as follows:

a) if you were audited: net income $=$ actual income - regular tax payment - additional payment

b) if you were not audited: net income $=$ actual income - regular tax payment

Example 3

Your actual income is 100 ECU, and you eventually declared your actual income:

Your regular tax payment $=100 \mathrm{ECU} \times 0.4=40 \mathrm{ECU}$

Your additional payment $=(100 \mathrm{ECU}-100 \mathrm{ECU}) \times 0.6=0 \mathrm{ECU}$

Your net income $=100 \mathrm{ECU}-40 \mathrm{ECU}-0 \mathrm{ECU}=60 \mathrm{ECU}$ 


\section{Example 4}

Your actual income is 100 ECU, and your eventually declared income 60 ECU:

Your regular tax payment $=60 \mathrm{ECU} \times 0.4=24 \mathrm{ECU}$

Your additional payment in the case of audit $=(100 \mathrm{ECU}-60 \mathrm{ECU}) \times 0.6 \mathrm{ECU}=40$

$\mathrm{ECU} \times 0.6=24 \mathrm{ECU}$

Your net income $=100 \mathrm{ECU}-24 \mathrm{ECU}-24 \mathrm{ECU}=52 \mathrm{ECU}$

Your additional payment in the case of no audit $=0$ ECU

Your net income $=100 \mathrm{ECU}-24 \mathrm{ECU}-0 \mathrm{ECU}=76 \mathrm{ECU}$

5) The regular tax payments of all group members are summed and multiplied by a factor of 1.2. Additional payments are not considered. The generated total tax revenue is redistributed in equal shares to group members.

Total tax revenue is calculated as follows:

Total tax revenue of the group $=$ sum of the regular tax payments of group members $\times$ 1.2

Your tax rebate is:

Tax rebate $=$ total tax revenue of group $/ 4$

Example 5

The sum of all regular tax payments in your group is 160 ECU.

Total tax revenue $=160 \mathrm{ECU} \times 1.2=192 \mathrm{ECU}$

Your tax rebate $=192 \mathrm{ECU} / 4=48 \mathrm{ECU}$

6) Your total income from the experiment is calculated as follows:

Total income $=$ net income + tax rebate

Example 6

Your actual income is $100 \mathrm{ECU}$, and you eventually declared your actual income.

Your net income $=100 \mathrm{ECU}-40 \mathrm{ECU}=60 \mathrm{ECU}$

Your tax rebate $=192 \mathrm{ECU} / 4=48 \mathrm{ECU}$

Your total income $=60 \mathrm{ECU}+48 \mathrm{ECU}=108 \mathrm{ECU}$ 


\section{Quiz}

Your answers to the quiz have no impact on the course of the experiment or on your income.

1. The experiment lasts several rounds [true/false]

2. Groups consist of four members [true/false]

3. Your income is known to all participants [true/false]

4. Tax rebates are split unequally [true/false]

5. Additional payments are included in the calculation of total tax revenue [true/false]

6. Your income is 80 ECU, your partner's income is 100 ECU.

(a) You and your partner declare your respective actual income. Calculate:

Your regular tax payment:

Your partner's regular tax payment:

(b) You declare your actual income, your partner declares 70 ECU. Calculate:

Your regular tax payment:

Your partner's regular tax payment:

(c) You declare 60 ECU, your partner declares his actual income. Calculate:

Your regular tax payment:

Your partner's regular tax payment:

(d) You declare 40 ECU, your partner declares 60 ECU. Calculate:

Your regular tax payment:

Your partner's regular tax payment:

7. Your income is 100 ECU, and you eventually declare an income of 80 ECU.

(a) You are audited. Calculate:

Your regular tax payment:

Your additional payment:

Your net income: 
(b) You are not audited. Calculate:

Your regular tax payment:

Your additional payment:

Your net income:

8. The sum of all regular tax payments in your group is 120 ECU. Calculate:

- The total tax revenue in your group:

- The tax rebate for the group members:

9. Calculate your total income of the experiment in the case that you were not audited. Use the results from questions 7 (b) and 8 .

Your total income: 


\section{Questions on tax evasion in Germany and social and personal norms}

1. What do you believe is the percentage of German taxpayers that have at least once deliberately filed their tax returns incorrectly or incompletely?

2. How strongly do you agree with the following statement: German taxpayers hold the opinion that it is acceptable to file their tax returns incorrectly or incompletely. (strongly disagree - 2 - 3 - 4 - strongly agree)

3. Do you believe it is acceptable to file tax returns incorrectly or incompletely? (strongly disagree - $2-3-4$ - strongly agree) 